\title{
Genetically Engineered Mouse Models in Preclinical Anti-Cancer Drug Development
}

\author{
Sergio Y. Alcoser and Melinda G. Hollingshead \\ Biological Testing Branch, Developmental Therapeutics Program, \\ National Cancer Institute
}

USA

\section{Introduction}

According to the most recent American Cancer Society data, an estimated 569,490 Americans died from cancer in 2010 (American Cancer Society [ACS], 2010). The number of cancer-related deaths recently surpassed those from heart disease in Americans $<85$ yrs old (Kung et al., 2008). Developing new and more efficacious anti-cancer compounds is a paramount health care priority. At the Developmental Therapeutics Program of the U.S. National Cancer Institute, potential therapeutic agents are typically tested for activity in an in vitro 60-tumor cell line screen and subsequently by in vivo xenograft studies in rodents (Figure 1). Once selected for additional testing using established criteria (drugability, novelty of structure and/or mechanism of action, potency, cell panel selectivity, etc.), additional studies (pharmaocokinetics, pharmacodynamics, range finding toxicity, formulation, mechanism of action analysis, IND-directed toxicology, etc.) are initiated followed by the progression of a selected few candidate agents into human clinical trials. Efficacious drugs with tolerable toxicity are ushered into early phase clinical trials. However, most of the promising compounds identified in the multi-layered preclinical screenings are not as successful in human patients. Therefore, preclinical models that better predict drug efficacy and toxicity in humans are needed. Differences in drug absorption, distribution, metabolism and elimination (ADME), immune responses and overinterpretation of the preclinical efficacy data may contribute to clinical failures. However, a significant limitation is generating mouse models that histologically, genetically, and behaviorally recapitulate the human disease.

Over the past twenty years, researchers have identified many of the underlying genetic abnormalities that cause certain cancers and have genetically engineered them into mouse models to explore the oncogenic nature of those genes and related pathways. The resulting mouse models generate tumors that may better mimic those seen in humans. It is anticipated that therapeutic compounds which show efficacy and low toxicity in these more human-like genetically engineered mouse (GEM) models will be more successful in clinical trials and lead to increased cancer survivorship. Hundreds of GEM models currently exist that are associated with some form of human tumor development (see the eMICE website). It is well beyond the scope of this manuscript to adequately describe each of them. We instead briefly review some of the ground-breaking GEM models developed in the 1980s and 90s, describe more recent and sophisticated models, highlight some of the advantages 
and limitations for each, and explore the potential roles of molecular targeted therapies and GEM models in preclinical drug testing. For additional details on each model, we refer the reader to the original articles or prior in-depth reviews. While mice that develop genetically engineered tumors hold much promise, the relatively slow growth rate of these tumors and their low penetrance (regardless of genetics, some mice will not develop tumors during the time constraints of the experiment) makes them ill-suited to replace xenograft models as the primary in vivo screening tool. Instead, we envision GEM models as an additional screening mechanism that narrows and optimizes the field of therapeutic compounds before expensive and time-consuming human clinical trials are initiated.

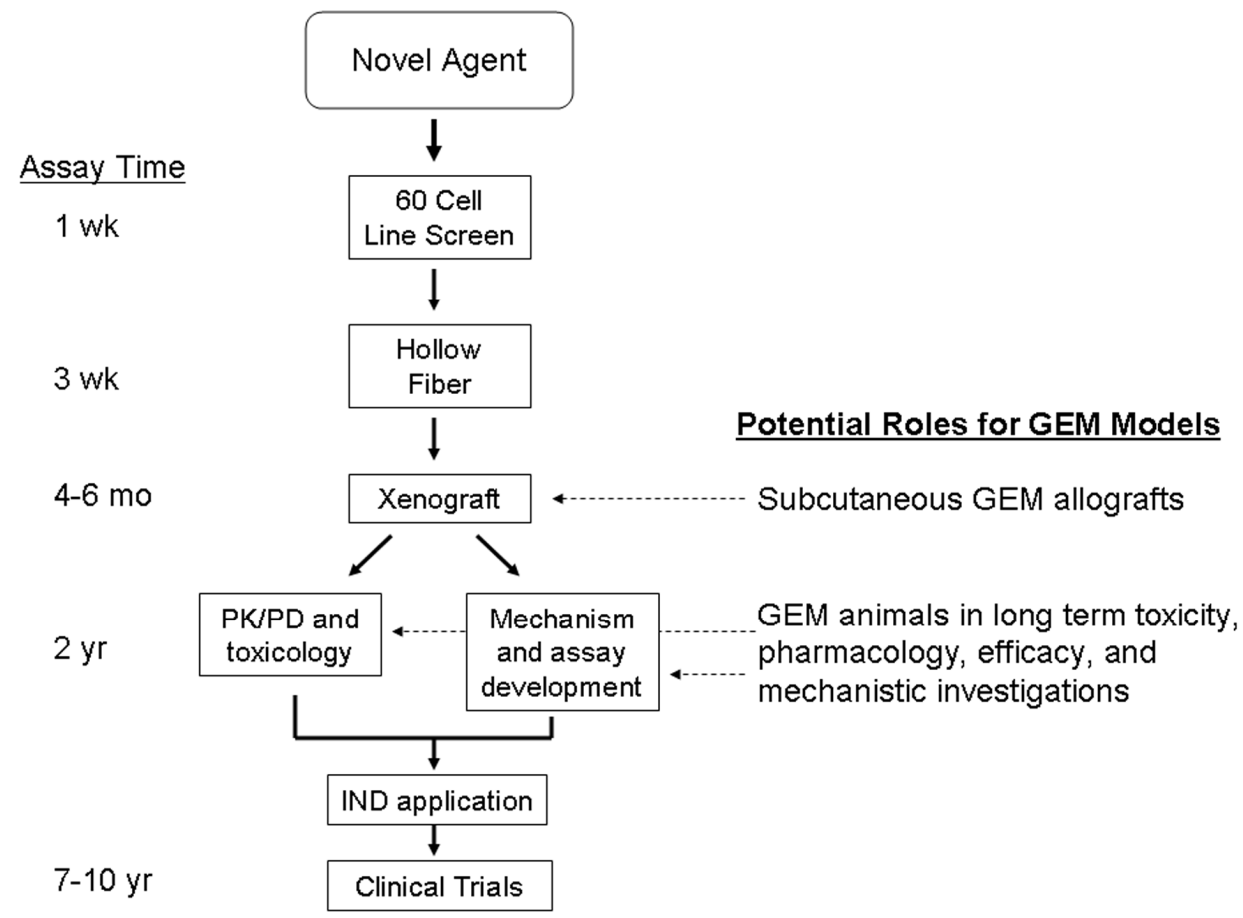

Fig. 1. Where GEMs Can Be Most Useful in the Preclinical Drug Development

Simplistic overview of preclinical drug development procedure in the NCI/DTP. Novel agents are introduced through the 60 Cell Line Screen (reviewed in Monks et al., 1991), which contains 60 human cultured tumor cell lines in a 96-well plate array. If antiproliferative activity is observed in a number of cell lines, the agent is tested in a Hollow Fiber assay, which measures the anti-proliferative activity in cultured cells grown in hollow polyvinylidene fluoride (PVDF) fibers implanted intraperitoneally and subcutaneously in mice (reviewed in Decker et al., 2004). If active in Hollow Fiber assays, agents are administered to immunodeficient animals that possess human tumors generated from serially passaged human tumor cell lines (xenografts). Tolerable toxicity and activity measurable in xenograft models leads to simultaneous investigations into the agent's 
PK/PD, mechanism of action and toxicology. Based on this data, where applicable an IND application is generated for FDA approval to initiate clinical trials. The agents may require further preclinical studies or can be approved for a small scale Phase 0 trial (reviewed in Murgo et al., 2008), or initial Phase I human clinical trials. Assay Time is a best case scenario for a single agent and does not include time for optimization and validation repetitions. PD = pharmacodynamics, $\mathrm{PK}=$ pharmacokinetics, $\mathrm{GEM}=$ genetically engineered mouse, $\mathrm{IND}=$ Investigational New Drug

\section{Background: in vivo drug screening using the human tissue xenograft}

After a potential therapeutic agent shows some activity in cultured tumor cell growth assays, its activity and toxicity are explored through in vivo xenograft models. Fragments of human tumors or cultured human tumor cells are implanted (often subcutaneously) into immunodeficient rodents. Once the tumors grow to a predetermined size, the potential anticancer agent is administered and the tumor response, generally assessed by tracking the tumor size, is measured over time. Drug doses and administration schedules are adjusted to optimize efficacy and to lower toxicity over several experimental cycles. This system generates valuable data and quickly returns a prediction on an agent's activity, often in several months. Unfortunately, promising anti-cancer compounds discovered through this route often fail in human clinical trials, commonly due to low efficacy (Kerbel et al., 2003; Sharpless \& DePinho, 2006). The low predictive value of these xenograft models exemplifies the need for better in vivo mouse models for preclinical drug testing.

\section{Birth of the transgenic "Oncomouse"}

Transgenic mouse technology has evolved from the early 1980s (reviewed in Palmiter \& Brinster, 1986) such that researchers can now conditionally and reversibly alter single gene expression. Thousands of publications have since supported the hypothesis that oncogene expression or tumor suppressor gene ablation in normal mammalian cells is sufficient to drive tumor development. The first report of a heritable tumor-prone transgenic mouse came in June 1984 (Brinster et al., 1984). These mice used the SV40 enhancer region to help drive expression of a construct consisting of the mouse metallothionein-1 gene promoter fused to the thymidine kinase gene from the herpes simplex virus (HSV). They included the whole SV40 upstream region, consisting of enhancer, promoter, and two T-antigen genes transcribed in the opposite direction. It was thought the T-antigen genes would be inactive in mice. Unexpectedly, they observed that the transgenic mice consistently developed brain tumors, as well as sporadic tumors in other tissues. Follow-up experiments showed that using only the SV40 enhancer/promoter region and the large T-antigen gene was sufficient to drive tumorigenesis (Palmiter et al., 1985). Subsequent reports have shown that expressing the large T-antigen in a specific cell type can promote tumor development. For example, Ornitz et al., (1985) demonstrated expression of the large T-antigen in acinar cells generated exocrine pancreatic tumors, whereas Hanahan (1985) used the insulin promoter driving the large T-antigen specifically in pancreatic beta-cells to produce endocrine pancreatic tumors.

Following the unexpected oncogenic ability of SV40, researchers tried to rationally design a tumor-generating transgenic mouse ("oncomouse"). In an effort to create a mouse model of a chromosomal translocation seen in some human B-cell lymphomas, Adams et al., (1985) 
generated a transgene consisting of an immunoglobulin enhancer $(E \mu)$ driving expression of the Myc gene. These mice heritably develop pre-B cell and mature B-cell lymphomas. Further studies by Strasser et al., (1990) showed that Myc required increased expression of the anti-apoptotic factor $\mathrm{Bcl}-2$ to drive tumorigenesis. Suppression of apoptosis is now understood to be a trademark of many cancer cells.

\subsection{MMTV induced breast cancer}

Using reciprocal matings between high tumor and low tumor mouse strains, Bittner (1936) reported tumor incidence in F1 females was dependent on the strain of the mother. Virologists demonstrated a virus (dubbed Murine Mammary Tumor Virus, MMTV) was responsible for inducing tumors in mammary tissue and was passed from mother to offspring through her milk. Subsequent studies showed some mouse strains also had MMTV virus in their eggs and sperm (reviewed in Heston \& Parks, 1977).

The utility of MMTV was expanded when it was shown that a short regulatory region (called long terminal repeat, LTR) was sufficient to confer hormone responsive and cellspecific expression in vitro (Huang et al., 1981). Stewart (1984) used the MMTV LTR to drive Myc expression in his transgenic mice that developed breast adenocarcinomas in mammary epithelial tissue. Since then the MMTV LTR has been fused with a variety of purported oncogenes to develop tumors in murine mammary tissue that are similar in morphology and gene expression profile to certain types of human breast cancers (reviewed in Robles \& Varticovski, 2008). For example, the MMTV-driven Polyoma Middle-T antigen (PyMT) model develops tumors similar to a human breast cancer with luminal type morphology approximately 2-3 months after birth (Guy et al. 1992). A model expressing MMTV-driven Wnt1 (wingless-type MMTV integration site family, member 1) generates mouse mammary tumors with characteristics similar to those of human basal type breast cancers (Huang et al., 2005). Several members of the Wnt gene family (encoding secretory glycoproteins that normally stimulate cell proliferation and differentiation) are expressed in the mouse mammary tissue during various stages of development. Wht-1 is not normally expressed in the mammary tissue; however, when driven ectopically by MMTV, it develops oncogenic properties. Like most of the other "first generation" transgenic oncomice, many of these models have a low tumor penetrance and widely variable latency period, making them difficult to use directly in large scale preclinical drug screenings. These limitations are partially overcome by resecting and transplanting transgenically induced tumors into many syngeneic recipient animals, generating a large cohort of tumor-bearing animals for drugscreening purposes (Maglione et al., 2004; Varticovski et al., 2007).

\subsection{Activated kras}

The KRAS2 gene encodes a G-protein that is a mammalian cellular homolog of a transforming gene isolated from the Kirsten RAt Sarcoma virus. This membrane-associated intracellular signal transducer plays a vital role in normal tissue signaling, proliferation, and differentiation (reviewed in Kranenburg, 2005). Several oncogenic point mutations interfere with the intrinsic GTPase activity of Kras, causing accumulation in a constitutively active GTP-bound state (Zenker et al., 2007). Expressing an activated Kras mutant transgene in acinar cells induces neoplasia in the fetal pancreas with large tumors developing only days after pancreatic differentiation (Quaife et al., 1987). Indeed, activating point mutations in the Kras gene have subsequently been shown to occur in 75 to $95 \%$ of spontaneous human 
pancreatic cancers (Almoguero et al., 1988) as well as $>90 \%$ of spontaneous and chemically induced mouse lung tumors (Malkinson 1998). Activated Kras expression in the mouse lung generates multiple tumors at an early age, so much so that the mice succumb quickly due to respiratory failure (Johnson et al., 2001). The varied penetrance and multi-focal primary tumor formation in addition to the short life span limits the use of this model in further studies of tumor development.

\subsection{Knockout oncomice}

The examples described thus far rely on the over expression of a nucleic acid sequence with purported oncogenic properties or mutations to drive tumorigenesis in mice. During the late 1980 's the use of homologous recombination in mouse embryonic stem cells enabled researchers to inactivate ("knockout") single genes. This technology created a new wave of transgenic oncomice beginning with the heterozygous null retinoblastoma $(\mathrm{Rb})$ mouse (Jacks et al., 1992). Rb inhibits the cell cycle by repressing expression of genes required for $S$ phase progression (reviewed in Hanahan \& Weiberg 2000). Mice lacking one Rb allele develop pituitary adenomas, whereas RB null offspring fail to develop beyond embryonic day 14 or 15 , possibly due to excessive neuronal cell death.

The importance of tumor suppressor expression became evident from this and other knockout mouse models. Various cellular stresses prompt p53 to modulate expression of its target genes, many of which regulate cell cycle arrest, apoptosis, DNA repair, or cellular metabolism. Decreased or null expression of p53 has been observed in numerous human cancers (reviewed in Harris \& Hollstein 1993). Mice lacking one or both p53 alleles are born normal but are predisposed to developing spontaneous lymphomas and sarcomas later in life (Donehower et al., 1992). Lacking a major tumor suppressor pathway, these p53 null mice became a useful background with which to elucidate the oncogenic potential of other genes. The $\mathrm{Rb} / \mathrm{p} 53$ double knockout mice develop highly aggressive tumors in the cerebellum visible as early as 7 weeks of age (Marino et al., 2000). Mammary and skin tumors develop frequently in female mice carrying conditional null Brca2 and p53 alleles (Jonkers et al., 2001), suggesting synergistic inactivation of Brca2 and p53 can mediate mammary tumorigenesis.

Since these early transgenic and knockout mouse models have genetic alterations which are expressed in the germline and most, if not all, somatic cells, the models are more representative of human cancer predisposition syndromes. This is not the case for most human cancers, which develop spontaneously in a small number of cells in the adult. Many genes have distinct functions and expression patterns during embryonic development that are still poorly understood and different from those in the adult. In addition, these early transgenic models are notorious for their variable penetrance and tumor latency, making it nearly impossible to accumulate the number of animals with synchronous tumor development needed for large studies. While large scale production of transgenic mice is now possible with IVF and other high production methods (JAX® Speed Expansion Service; Charles River Laboratories Rapid Expansion Services), it does not obviate the issue of variable penetrance and tumor latency; it simply provides a large number of animals that can be held simultaneously to observe for tumor development. Early GEM models generated multiple primary lesions which far exceeded that observed in humans, limiting their predictive value and usefulness for preclinical studies. To better model most human cancers, genomic alterations should only occur in a small number of cells in the adult mouse tissue corresponding to the microenvironment in which the human cancer develops. 
1)

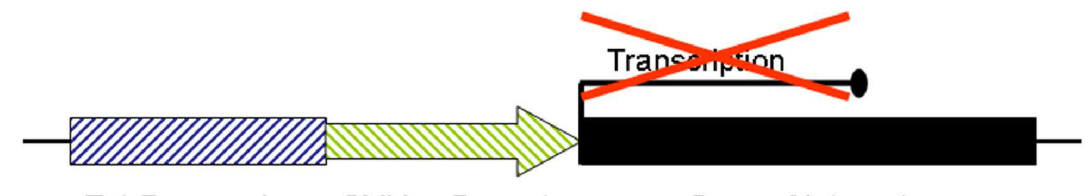

Tet-Responsive $\mathrm{CMV}_{\min }$ Promoter Element

Gene of Interest Element

2)
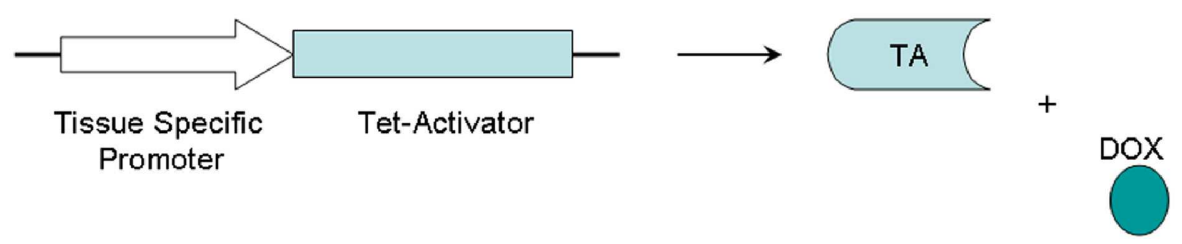

3)

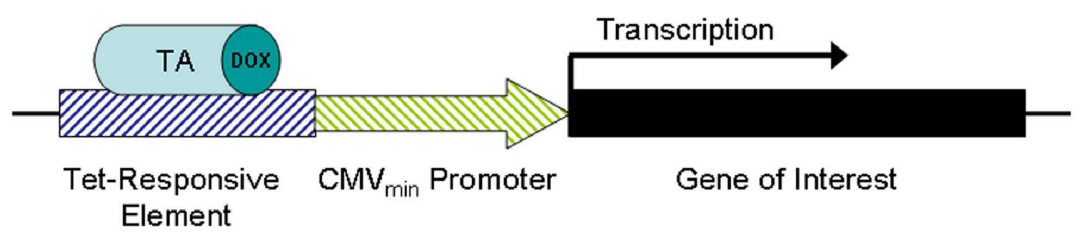

Fig. 2. Schematic Representation of the Tet-ON system; 1) Without the Tet-Activator (TA), the transgene consisting of the Gene-of-Interest (GOI) fused to the Tet-Responsive Element (TRE) will not be expressed. 2) Doxycycline can bind to the Tet-Activator protein, altering its protein structure such that TA can now bind to a TRE. 3) If both the Tet-Activator and the TRE-GOI transgenes are present in the same cell, upon doxycycline administration and TA activation, the GOI will be transcriptionally active.

\section{Conditional and inducible oncogene expression}

The ability to alter gene expression in a normal adult mouse overcomes many confounding factors gene manipulation might have in embryonic development and may better recapitulate human disease. A widely used inducible system is the Cre-Lox model (reviewed in Le \& Sauer, 2001; Brault et al., 2007), where a segment of DNA is flanked by 34 base-pair (bp) LoxP sites (then referred to as floxed DNA). Co-expression of the Crerecombinase (by crossbreeding with a tissue-specific Cre mouse (Nagy \& Mar, 2001), or infecting with a virus carrying Cre) causes the region between the LoxP sequences to be spliced out (including all or part of the gene of interest) of the genome of that individual cell. Researchers have used this method to permanently silence genes in mice. There are two main limitations to the Cre-LoxP technology. The first obstacle is resolving how to administer Cre such that expression occurs only in the cells of interest. Crossing floxed mice with mice constitutively expressing Cre in a specific tissue often results in their offspring containing the deletion from the embryonic stage. It is difficult to administer Cre in the 
adult animal in a tissue-specific manner. The second limitation is the Cre-recombination event is irreversible and heritable.

To overcome some of these limitations, researchers have developed the Tet-ON/OFF system (reviewed in Sprengel \& Hasan, 2007). It requires co-expression of two transgenes in a given cell, usually accomplished by cross-breeding. Driven by a user defined promoter, the first transgene generates the inactive Tetracycline Activator (TA). Doxycycline (a more potent isoform of the antibiotic tetracycline) can bind to and activate TA, which can bind the Tetracycline Response Element (TRE) on the second transgene and drive expression of its gene of interest (see Figure 2). Researchers use this system to initiate gene expression in adult animals through doxycycline administration in their chow. Since the oncogene expression is tied directly to the presence of doxycycline in their diet, the oncogene can be activated or silenced simply by adjusting an animal's diet. The main limitation to this procedure is the upfront time and labor needed to create mice that express the Tet-operator transgene and separate models expressing the tissue-specific Tet-activator transgene, then crossbreeding them to generate bi-transgenic offspring.

Both of these inducible expression systems can be used in reverse as well if the transgene constructs are designed accordingly. The Cre-recombinase can excise a multiple STOP cassette (Lox-STOP-Lox, LSL) integrated upstream of a transcription start site, enabling transcription of a previously silenced gene (see Figure 3). The Tet-ON/OFF system allows gene expression to be repeatedly induced or silenced in multiple cycles simply by providing or removing doxycycline from the animal's diet. However, the system was shown to be leaky in some early studies, resulting in incomplete expression inhibition or a low level of unregulated basal transcription. Adjunct technologies are continually being developed to obtain tighter gene expression control (reviewed in Freundlieb et al., 1999; Bockamp et al., 2007) which make these systems more robust, accurate, and thus more reliable as preclinical models. The following examples highlight the utility of inducible GEM tumor models.

\subsection{Conditional cre-lox kras G12D system}

Taking advantage of the Lox-Stop-Lox conditional transgene expression system, Jackson et al., (2001) created a transgenic mouse model which replaces one wild type Kras allele with a transcriptionally silent oncogenic Kras-G12D allele. Intranasally delivered adenovirus containing the Cre-recombinase (adeno-Cre) splices out the LSL and enables expression of the activated Kras-G12D transgene in the lung. Small lesions can be seen 2 weeks post induction; by 12 weeks post induction, adenomas are observed, some with cytogenic characteristics of malignancy. By 16 weeks post induction, large adenomas and adenocarcinomas are present in many animals. Virus titrations in a number of animals demonstrate that the number of virus particle equivalents used for induction is directly related to the number of tumors that develop.

Around the same time, Fisher et al., (2001) created an activated Kras Tet-ON/OFF inducible model. Doxycycline (DOX) administration induces expression of the murine oncogenic Kras G12D allele in alveolar type II pneumocytes. Hyperplasia is observed after just seven days of DOX administration; at eight weeks post induction, adenomas and adenocarcinomas are observed in the lungs. Removal of DOX from their diet causes a rapid decrease in activated Kras expression (within seven days) and apoptotic regression of the tumors. One month after DOX withdrawal, lesions and tumors were no longer present in the lungs, implying expression of the mutant Kras gene product was required to maintain the viability of tumor 
cells. The requirement of continued oncogene expression (or constant inhibition of tumor suppressor) to maintain the induced tumors has given rise to the theory of "oncogene addiction" (reviewed in Weinstein, 2002).

1)
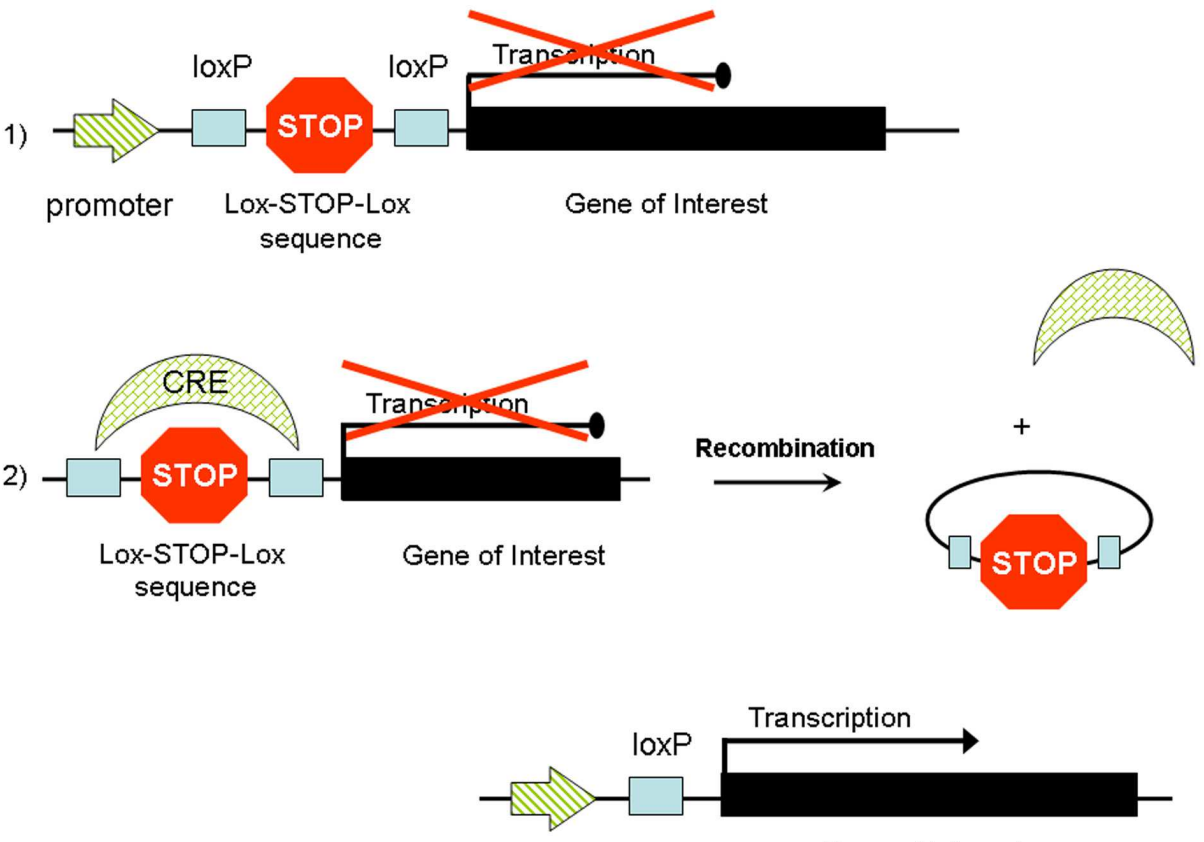

Gene of Interest

Fig. 3. CRE Recombination Mediates Lox-Stop-Lox Gene Activation. One popular method of inducing gene expression in adult mice is to use CRE recombination. 1) The transgenic mouse initially has the Lox-STOP-Lox sequence inserted upstream of the transcription start site for the gene of interest (GOI). This prevents GOI expression until acted upon by CRE. CRE recombinase is introduced to the appropriate cell population either by crossing with a second transgenic mouse expressing CRE recombinase using a tissue specific promoter, or by administering a virus expressing CRE recombinase in a tissue specific manner. 2) CRE recombinase splices out the STOP sequence between the two loxP sites from the transgenic DNA sequence, allowing GOI expression.

Sos et al., (2009) recently used computational genomic analysis to identify molecular and genetic predictors of therapeutic response to clinically relevant compounds in various NSCLC cancer cell lines which are highly representative of primary tumors. One of their findings was that cells expressing activated Kras also had enhanced Hsp90 dependency. They used the LSL-KrasG12D model to verify this observation. Mice were initially imaged by MRI 12-20 weeks post adeno-Cre administration, then split into placebo and 17(Dimethylaminoethylamino)-17-demethoxygeldanamycin (17-DMAG a well-known Hsp90 inhibitor) groups. Mice were imaged by MRI after 1 week of drug treatment; tumor volume was decreased by $50 \%$ in 17 -DMAG treated mice while tumor volume increased slightly in placebo treated animals. Prior to this study, there were no molecular targeted treatments for 
activated oncogenic Kras-driven lung tumors. But by combining the power of computational genomics and GEM models, researchers were able to rationally identify a possible therapeutic modality and evaluate its efficacy in vivo.

\subsection{Inducible oncogenic mutations in the EGF receptor}

The epidermal growth factor receptor (EGFr) is a transmembrane cell surface receptor which is mutated or alternatively expressed in a significant proportion of human gliomas and adenocarcinomas (especially of the head and neck, breast, colon, lung, and pancreas). EGFr is the human homolog of neu, a rat gene first identified in ethyl nitrosourea induced tumors (reviewed in Maguire \& Greene, 1989), and is a member of the erythroblastic leukemia viral oncogene/human epidermal growth factor receptor (ERBB/HER) receptor tyrosine kinase family. Two of the most commonly observed EGFr mutations seen in lung adenocarcinomas include an in-frame deletion in exon 19 (eliminating an L-R-E-A [leucine-arginine-glutamic acid-alanine) amino acid motif that is conserved in all known vertebrate EGFr sequences) and a point mutation which results in a leucine to arginine substitution at position 858 . These and other less common mutations in the kinase domain of EGFr are associated with increased therapeutic sensitivity to tyrosine kinase inhibitors such as gefitinib and erlotinib. Several studies demonstrated significantly extended survival and time to progression (TTP) in non-small-cell lung cancer (NSCLC) patients treated with gefitinib as their first line therapeutic (Han et al., 2005; Sequist et al., 2008; Yang et al., 2008). Erlotinib administration in patients who have had prior chemotherapy has an even greater survival benefit and is currently recommended by the FDA for second line therapy in new NSCLC patients (Shepherd et al., 2005). Inducible transgenic mouse models help to clarify this observation and provide a system to test other therapeutics that operate through the EGF receptor.

Politi et al., (2006) generated several Tet-ON/OFF mouse systems which overexpress various mutant EGFr alleles upon DOX administration. Lung adenocarcinomas were observed after two months post transgene induction in the exon 19 deletion and L858R transgenic EGFr mouse models. Similar to the Tet On/OFF activated Kras system, after one month of DOX withdrawal the observed tumor load in the EGFr transgene inducible models regressed to near pre-induction histology. To test the anti-tumor efficacy of an already clinically approved therapeutic in this model, the tyrosine kinase inhibitor erlotinib was administered to groups of transgenic EGFr mice maintained on DOX. After less than a week of erlotinib treatment, all of the animals which received at least $12 \mathrm{mg} / \mathrm{kg} / \mathrm{d}$ showed partial or complete responses by magnetic resonance imaging (MRI). Longer lengths of treatment correlated with greater tumor regression. Ji et al., (2006) generated similar inducible EGFr transgenic mice (exon 19 in-frame deletion or L858R), but also added a luciferase fusion gene to the construct. This allows for the monitoring of lung tumor growth and regression in vivo using a non-invasive luciferase imaging system. The ability to non-invasively image tumor load repeatedly in vivo enables the effects of anti-cancer drug administration to be followed long term as the authors demonstrated with cetuximab.

\subsection{GEMs possessing multiple genetic alterations}

Patients with lung adenocarcinomas containing one of the common EGFr oncogenic mutations (deletion in exon 19 of the kinase domain [Del.ex19] and leucine 858 to arginine[L858R]) are sensitive to the EGFr-tyrosine kinase inhibitor (TKI) therapies (gefitinib and erlotinib). However, the TKI treated tumors invariably relapse within a year by 
developing resistance to the TKI therapy (reviewed in Morita et al., 2009), most commonly through one of the following mechanisms: EGFr-T790M point mutation (Kobayashi et al., 2005; Pao et al., 2005), MET proto-oncogene amplification (Engelman et al., 2007), or hyperphosphorylation and activation of insulin-like growth factor-I receptor (Guix et al., 2008). The EGFr-T790M mutation (observed in 50\% of relapsed EGFr-mutant tumors) is thought to increase the ATP-binding affinity by an order of magnitude (Yun et al., 2008), thereby reducing the therapeutic ability of TKIs to out-compete ATP for receptor binding. MET amplification is thought to induce gefitinib resistance primarily by driving ERBB3 (HER3)-dependent activation of the PI3K and Erk pathways, which regulate cell survival and mitogenesis, respectively (reviewed in Kim \& Salgia, 2009).

To overcome the acquired resistance of first generation TKIs, researchers have recently developed TKIs that bind EGFr irreversibly and are currently in or have completed phase II clinical trials (reviewed in Riely, 2008). The pan-ERBB inhibitor HKI-272 covalently binds to a cysteine in the EGFr kinase domain and regressed tumors at nanomolar concentrations in EGFR-L858R transgenic mice (Ji et al., 2006). The ability to inhibit ERBB2 (HER2) has led HKI-272 to be investigated primarily in breast cancer clinical trials (clinicaltrials.gov, 2011). However, other cancers driven by ErbB mutations may also be treated by HKI-272. Similarly, the irreversibly binding EGFr and HER2 inhibitor BIBW2992 is being tested in over 20 clinical trials of patients with advanced NSCLC, breast cancer, prostate cancer, malignant gliomas, and other solid tumors (clinicaltrials.gov, 2011). In addition to ERBB inhibitors, researchers are investigating other druggable targets related to the EGFr/HER2/ERK/AKT pathways. Shimamura et al., (2008) used an EGFR-L858R-T790M double transgenic GEM model to test the efficacy of an Hsp90 inhibitor, CL-387,785. Hsp90 is a chaperone thought to aid in the proper folding of EGFr; CL-387,785 binds irreversibly to Hsp90 thereby interfering with its chaperone function.

Cancer-related lethality in humans is often caused by the invasion of metastatic tumors in tissues far from the primary tumor. Yet few single transgene GEM models reliably develop metastatic lesions. By crossbreeding the pancreas-specific Cre-mediated activated Kras GEM (which alone generates only pre-malignant neoplasia) and the Ink4a/ARF conditional knockout models (does not induce neoplasia), Aguirre et al., (2003) generated mice that rapidly develop invasive, metastatic ductal pancreatic tumors which are lethal by 11 weeks. This tumor development is similar to the highly lethal human form of pancreatic ductal adenocarcinoma. Although the rapid murine mortality prevents long term studies, it may nevertheless be a useful model of a deadly human malignant cancer in short-term or cancerprevention studies.

Similarly, Ji et al., (2007) crossed a lung-specific activated-Kras GEM with the following tumor suppressor knockout GEMs: Ink4a, p53, or the serine/threonine kinase 11 (Lkb1) knockout. Among the dual-knockout mice analyzed, the activated Kras x Lkb1 knockout had the most profound phenotype. These mice display a significantly increased lung tumor burden, rapid tumor onset, and $<50 \%$ shorter survival when compared to the other double crosses or single knockout models examined. Regional lymph-node metastases were observed in $61 \%$ of the activated Kras $x$ Lkb1 knockout mice, significantly more than the other models. The results from the previous few examples suggest an activating Kras mutation is responsible for initial neoplasia development, but a second mutated gene modulates the aggressiveness and metastatic behavior of the cancer. Accumulation of somatic mutations over time has long been a theory to explain the modulation and late onset of cancer in humans. 
Winslow et al., (2011) expanded on this idea by administering a lentivirus expressing Cre recombinase to a double floxed GEM model. Upon CRE recombination, activated Kras would be expressed and p53 (flox/flox) would be silenced in certain cells of the adult lung. Because the lentivirus integrates randomly into the host cell's genome, the authors were able to use linkage-mediated PCR (LM-PCR) to generate a unique "fingerprint" for each primary tumor and monitor that "fingerprint" in any subsequent metastases. Although virus was delivered at a set time point and many primary foci seemed to successfully undergo the oncogenic double recombination event, only a few primary foci were responsible for generating macroscopic metastases outside the lung, suggesting other genetic or microenvironmental factors control a tumor's metastatic potential. This is an excellent example of using an inducible, double GEM to model genetic alterations seen in many human lung cancers and explore the genetics of malignant and non-malignant tumors.

Tp53 is not the only tumor suppressor being actively investigated using GEM models. The tumor suppressor phosphatase and tensin homologue (PTEN) is a lipid phosphatase which negatively regulates the PI3/AKT pathway, which is often upregulated in human malignancies. Sixty percent of primary human prostate cancers show a decrease/loss of PTEN expression; this gene also is deleteriously mutated in $70 \%$ of gliomas and in some forms of breast carcinomas and melanomas (Gray et al., 1998). To investigate the role of PTEN in prostate cancer, Trotman et al., (2003) created several PTEN GEM models, each with a different level of PTEN expression. Only the homozygous PTEN knockout show a significant phenotype (invasive prostate cancer develops after six months in all mice). However, none of the models generate metastases and the mice do not have decreased survival compared to wild type controls. A prostate-specific PTEN conditional knockout was created which also generated invasive prostate cancer; but in this case metastatic prostate tumors developed and were found in the lymph and lung (Wang et al., 2003). Concomitant inactivation of one or both Cdkn1b (encodes the tumor suppressor p27) alleles in a heterozygous PTEN knockout mouse accelerates spontaneous neoplasia formation which develop into prostate carcinoma at complete penetrance within three months from birth (Di Cristofano et al., 2001). When a conditional PTEN knockout mouse is crossed with a p53 knockout mouse the resulting offspring is a conditional double knockout GEM that develops aggressive, lethal prostate cancer with complete penetrance in seven months (Chen et al., 2005). The cancers observed in this new generation of GEM models recapitulate the progression and histopathologic features of some forms of prostate cancer observed in humans. These studies highlight the role of PTEN in tumorigenesis and the need for additional cooperative tumor suppressor inactivation to generate malignancies and lethal cancers.

The potential for drug discovery and validation using conditional GEM models is demonstrated with the Brca1/p53 mouse model. The majority of human BRCA1-associated tumors harbor mutations in both p53 and BRCA1. Poole et al., (2006) created such a CreLoxP conditional GEM model by inactivating both p53 and Brca1 specifically in the mouse mammary gland. The authors found that progesterone receptors are overexpressed in mutant mammary epithelial cells and presented a possible avenue of treatment. Administration of a progesterone agonist (mifepristone, RU 486) prevented mammary tumorigenesis in Brca1/p53-deficient mice. As the potential to genotype a patient's tumor to determine their status for EGFr, MET, p53, IGF, and other important neoplasia-associated targets becomes practical, it will be possible to better choose the optimal combination therapy to impact the relevant oncogenic pathways. 


\section{The predictive potential of GEMs}

The potential predictive power of transgenic mice can be illustrated in the example of thiazolidinediones (TZDs). As an agonist of peroxisome proliferator-activated receptorgamma (PPAR $\gamma$ ), the TZD troglitazone had been an FDA-approved therapy for type-2 diabetes. TZD anti-tumor activity in cultured and xenografted human colon cancer cells prompted excitement in the scientific community that initiated its use in Phase II clinical trials in patients with colon cancer (Sarraf et al., 1998). However, in a study published a few pages after the xenograft study, troglitazone showed no anti-tumor activity in Min+/- mice; in fact, polyp formation increased with troglitazone administration in this model (Saez et al., 1998). This heterozygous knockout mouse model lacks one functional copy of the APC tumor suppresser gene, thus predisposing them to colon cancer. In the Phase II clinical trial patients treated with troglitazone actually showed disease progression within months of therapy initiation, correlating with the results predicted from the transgenic mouse model (Kulke et al., 2002).

\subsection{Cautionary tale}

Although many regard mice as "little fuzzy humans" in the analysis of preclinical data, there are vast and often unknown differences in drug metabolism, gene expression, and disease progression between the murine model and humans. One example of transgenic mouse models failing to accurately predict human clinical outcome is the Farnesyltransferase (FTase) story. FTase catalyzes the post-translational farnesylation of proteins containing a C-terminal CAAX motif, where $\mathrm{C}$ is the cysteine residue to be farnesylated, A represents an aliphatic amino acid, and $X$ is any amino acid. When $X$ is leucine, the protein is a preferred substrate for a similar enzyme named geranylgeranyltransferase I (GGTase).

Mendola \& Backer, (1990) showed farnesylation of Ras proteins is critical for their transformation into potent oncogenes. This discovery ignited the hypothesis that interfering with prenylation using inhibitors of FTase (FTIs) or GGTase (GGTIs) could lead to tumor growth inhibition and a viable anti-cancer therapy. Although some data suggest an FTI and a GGTI need to be utilized simultaneously to achieve complete inhibition of Kras prenylation (Rowell et al., 1997), FTIs alone had been shown to inhibit growth of human tumor xenografts in nude mice (Sun et al., 1998). FTI monotherapy also demonstrates beneficial effects in transgenic mouse models: tumor regression in H-Ras mice (Kohl et al., 1995), tumor stasis in N-Ras mice (Mangues et al., 1998), and tumor growth inhibition in KiRasB mice (Omer et al., 2000). These results and others spurred excitement for FTI monotherapy in clinical trials. With the exception of a few trials in breast cancer and leukemia patients, FTIs used as single agents have not shown good efficacy against solid tumors (reviewed in Zhu et al., 2003). Thus, none of the various mouse models evaluated were able to predict drug efficacy in humans. However, many clinical trials are currently underway combining FTIs with other drugs including "classical" anticancer therapies (chemotherapy or radiotherapy) and molecular targeted therapeutics.

\subsection{Targeted molecular therapeutics}

For decades, cancer therapy has been one or a combination of the following three treatments: surgery, radiotherapy, and cytotoxic chemotherapy. However, all have their limitations and substantial side effects. Ideally, anti-cancer treatments would "target" cancer 
cells and minimize adverse effects to non-cancerous cells. Tumors often contain gene expression profiles and mutations that make them more or less sensitive to some targeted therapies than others. Identifying the tumor's gene expression profile and correlating it to the most successful therapies for that specific profile will keep therapeutic adverse side effects to a minimum and yield the best prognosis for the patient.

The two main types of targeted molecular therapies are monoclonal antibodies, which target the receptor's extracellular domain, and small molecule inhibitors, which target the intracellular signaling and kinase domains. Table 1 outlines some of the FDA-approved targeted therapeutics, their molecular targets, and the forms of cancer in which they have been proven to have a clinical benefit. Monoclonal antibodies (mabs) are generally administered no more than once weekly by intravenous injection, whereas small molecules (nibs) can generally be taken orally each day. Currently available targeted therapies may be administered as single agents, but many show greater benefits in combination with other agents or in addition to traditional therapies in those patient populations with tumors of susceptible genetic profiles. Tumors can be generated in genetically engineered mice which have these susceptible mutations and expression profiles, providing researchers with valuable preclinical drug screening opportunities.

Herceptin (HER2) is a transmembrane receptor that is over-expressed in $20-25 \%$ of breast cancers and is associated with aggressive tumor behavior and poor prognosis (reviewed in Nanda, 2007). Two early studies have shown the anti-HER2 monoclonal antibody trastuzumab plus chemotherapy significantly improves overall survival in HER2+ patients with metastatic breast cancer (Slamon et al., 2005). Antibody binding is thought to inhibit HER2 signaling, which disrupts DNA repair mechanisms and induces cytotoxicity. Resistance to trastuzumab commonly occurs and can render this treatment useless in subsequent relapses. A recent advance has been to conjugate the antibody with a toxin/drug, thereby creating a "guided missile" that targets a specific epitope overexpressed on cancer cells and delivers the toxic agent to those specific cells. Researchers at Genetech harvested mammary tumors from MMTV-HER2 transgenic mice, implanted them orthotopically into a large cohort of nude mice, staged the mice when mean tumor volumes were $\sim 100-200 \mathrm{~mm}^{3}$, and administered their trastuzumab-DM1 (T-DM1) conjugate at various time points and doses (Jumbe et al., 2010). DM1, also known as maytansine and derived from members of several tropical plant families, is a potent cytotoxin that irreversibly inhibits tubulin polymerization and arrests cells in M or G2 phase (Remillard et al., 1975; Rao et al., 1979). Because the toxin is specifically targeted to tumor cells, the authors saw no adverse events in the mice, with $\sim 50 \%$ of the tumors showing complete regression at doses of $15 \mathrm{mg} / \mathrm{kg}$ given once every three weeks. PD/PK measures were obtained from the mice and this immunoconjugate therapy is now being evaluated in several clinical trials in patients with metastatic breast cancer.

Several therapeutics have been developed that target the EGFr receptor to treat non-small cell lung cancer and colorectal cancer, including cetuximab, panitumumab, erlotinib, and gefitinib. Tumors expressing EGFr with a deletion in exon 19 or sensitizing point mutation (L858R) in the ATP-binding pocket respond significantly better to gefitinib than patients with wild type EGFr (Lynch et al., 2008). Invariably, even the tumors with increased drug sensitivity relapse when resistance to gefitinib develops. Additional therapeutics need to be generated to overcome the inevitable drug resistance. 


\begin{tabular}{|c|c|c|}
\hline Targeted Therapy & Molecular Target & Approved Use \\
\hline cetuximab (Erbitux $\left.{ }^{\circledR}\right)$ & EGFr & Colorectal Cancer \\
\hline erlotinib $\left(\right.$ Tarceva $^{\circledR}$ ) & EGFr & $\begin{array}{l}\text { Non-Small Cell Lung Cancer } \\
\text { Metastatic Pancreatic Cancer }\end{array}$ \\
\hline gefitinib (Iressa ${ }^{\circledR}$ ) & EGFr & Non-Small Cell Lung Cancer \\
\hline panitumumab (Vectibix $\left.{ }^{\circledR}\right)$ & EGFr & Colorectal Cancer \\
\hline trastuzumab $\left(\right.$ Herceptin $\left.^{\circledR}\right)$ & HER2 & Early and Metastatic Breast Cancer \\
\hline lapatinib (Tykerb ${ }^{\circledR}$ ) & HER2 and EGFr & Breast Cancer \\
\hline $\begin{array}{l}\text { bevacizumab } \\
\left.\text { (Avastin }^{\circledast}\right)\end{array}$ & VEGF & $\begin{array}{l}\text { Metastatic Colorectal Cancer } \\
\text { Metastatic Melanoma } \\
\text { Non-Small Cell Lung Cancer }\end{array}$ \\
\hline sunitinib $\left(\right.$ Sutent $\left.{ }^{\circledR}\right)$ & VEGFr and PDGFr & Metastatic Renal Cell Carcinoma \\
\hline $\begin{array}{c}\text { sorafenib } \\
\left(\text { Nexavar }^{\circledR}\right)\end{array}$ & $\begin{array}{l}\text { Multi-Targeted } \\
\text { Kinase Inhibitor }\end{array}$ & Metastatic Renal Cell Carcinoma \\
\hline $\begin{array}{l}\text { toceranib } \\
\left.\text { (Palladia }^{\circledR}\right)\end{array}$ & $\begin{array}{l}\text { Multi-Targeted } \\
\text { Kinase Inhibitor }\end{array}$ & Canine Specific Mastocytoma \\
\hline $\begin{array}{l}\text { pazopanib } \\
\left(\text { Votrient }^{\circledR}\right)\end{array}$ & $\begin{array}{l}\text { VEGFr, PDGFr, and } \\
\text { cKIT }\end{array}$ & Advanced Renal Cell Carcinoma \\
\hline $\begin{array}{l}\text { imatinib } \\
\left(\text { Gleevec }^{\circledR}\right)\end{array}$ & $\begin{array}{l}\text { cKIT, ABL, and } \\
\text { PDGFr2 }\end{array}$ & Chronic Myeloid Leukemia and GIST \\
\hline $\begin{array}{l}\text { dasatinib } \\
\left.\text { (Sprycel }^{\circledR}\right)\end{array}$ & $\begin{array}{l}\mathrm{BCR} / \mathrm{ABL} \text { and } \mathrm{Src} \\
\text { Family }\end{array}$ & $\begin{array}{c}\text { Chronic Myeloid Leukemia with resistance to prior } \\
\text { therapy }\end{array}$ \\
\hline $\begin{array}{c}\text { alemtuzumab } \\
\text { (Campath }{ }^{\circledR}, \text { MabCampath }{ }^{\circledast} \\
\left.\text { or Campath- } 1 \mathrm{H}^{\circledast}\right)\end{array}$ & $\begin{array}{l}\text { CD52 on Mature } \\
\text { Lymphocytes }\end{array}$ & $\begin{array}{l}\text { Chronic Lymphocytic Leukemia (CLL) and } \\
\text { Cutaneous T-cell Lymphoma (CTCL) }\end{array}$ \\
\hline ofatumumab (Arzerra ${ }^{\circledR}$ ) & CD20 on B-cells & Chronic Lymphocytic Leukemia (CLL) \\
\hline $\begin{array}{c}\text { rituximab } \\
\left(\text { MabThera }^{\circledR} \text { and Rituxan }{ }^{\circledR}\right)\end{array}$ & CD20 on B-cells & B-cell Non-Hodgkin's Lymphoma \\
\hline $\begin{array}{c}\text { nilotinib } \\
\left(\text { Tasigna }{ }^{\circledR}\right)\end{array}$ & $\begin{array}{l}\text { BCR/ABL kinase } \\
\text { inhibitor }\end{array}$ & $\begin{array}{l}\text { Philadelphia chromosome positive chronic myeloid } \\
\text { leukemia (CML) }\end{array}$ \\
\hline vandetanib (Zactima $\left.{ }^{\circledR}\right)$ & VEGFr, EGFr, RET & Metastatic Medullary Thyroid Cancer \\
\hline
\end{tabular}

EGFr: Epidermal growth factor receptor; erythroblastic leukemia viral (v-erb-b) oncogene homolog 1

VEGFr: Vascular endothelial growth factor receptor

PDGFr2: Platelet-derived growth factor receptor-alpha

$B C R / A B L:$ c-abl oncogene 1, receptor tyrosine kinase

cKIT: v-kit Hardy-Zuckerman 4 feline sarcoma viral oncogene homolog

Her2: Herceptin receptor; v-erb-b2 erythroblastic leukemia viral oncogene homolog 2

RET: "Rearranged during transfection" proto oncogene

Table 1. An overview of the currently FDA approved targeted therapy compounds. 
Since vascularization is required for growth and health of a tumor, the angiogenesis associated factor VEGF became a desired target for therapy. Bevacizumab is an anti-VEGF antibody which has been shown to bind and inhibit VEGF, slowing angiogenesis and aiding in solid tumor starvation and elimination (Brekken et al., 2000). When used as single agents in unsorted cancer patients, anti-angiogenic therapeutics do not show significant activity. However, when used in combination with other therapies (especially cytotoxic chemotherapy), subgroups of patients show promise (reviewed in Cabebe, 2007). Bevacizumab, in addition to paclitaxel and a platinum cytotoxic agent, is now part of a first line therapy for newly diagnosed non-small cell lung cancer. Hundreds of Phase II and Phase III trials using bevacizumab in combination with other therapies in many other cancers are currently ongoing (clinicaltrials.gov, 2011).

\subsection{GEM oncomice in cancer prevention}

GEM models are beginning to realize their potential as preclinical models of cancer prevention (briefly reviewed in Abate-Shen et al., 2008). In a recent example, Ohashi et al., (2009) used the EGFR-L858R-FLAG transgenic mouse to test the cancer preventative potential of gefitinib administration. Twenty-five 3-week old transgenic mice were administered gefitinib, with 5, 5, and 15 mice euthanized at weeks 8, 13, and 18, respectively. At termination the lungs tumors were counted and measured macroscopically and histologically. Those receiving gefitinib failed to develop adenocarcinomas, whereas the groups given vehicle control developed hyperplastic regions at 5 weeks and large adenocarcinomas by 15 weeks. One week after cessation of the 15-week gefitinib administration period, the transgenic mice showed signs of hyperplastic cell expansion in the lung (by PCNA staining), suggesting gefitinib was the lone factor preventing EGFrL858R tumor development in these mice. Longer term studies are needed to see if the EGFrL858R transgenic mice eventually develop gefitinib resistance, as is seen in human NCSLC patients with EGFr-L858R driven lung tumors. Similar studies with erlotinib, other tyrosine kinase inhibitors, and novel anti-cancer agents should be performed on this and other informative GEM models to further investigate the tumor-preventative aspects of these agents.

\subsection{Cancer vaccine}

It is conceivable that patients with a high risk (family history, environmental exposure, or heritable mutations) associated with a specific cancer subtype might benefit from being immunized at a young age. Vaccine development depends on the identification of antigens specific for a given cancer subtype or tumor-inducing biological agent. The heterogeneity and unstable genome in most cancers suggests resistant mutant cells might accumulate quickly and overcome the immunotherapy. However, vaccines against oncogenic strains of viruses have proven to be very beneficial and often lean on the preclinical use of GEM models to show the oncogenic potential of viral genes.

In 1993, two studies using transgenic mice emerged clearly showing the oncogenic potential of the human papillomavirus (HPV) early genes E6 and E7 (Lambert et al., 1993; Arbeit et al., 1993). HPV DNA has also been found in and hypothesized by some to induce a subset of tongue and other oropharyngeal carcinomas (reviewed in Syrjänen, 2005). Transgenic mice expressing HPV early genes have been used to demonstrate the oncogenic potential of HPV in certain skin cancers [HPV 8 (Schaper et al., 2005) and HPV 20 (Michel et al., 2006)]. Spurred by these and many studies elucidating the relationship between HPV and cervical 
cancer, the FDA approved the HPV vaccine Gardasil (Merck) for preventing the most common forms of human papillomavirus (HPV)-induced cervical cancer (reviewed in McLemore, 2006). Feng et al., (2008) recently discovered a novel polyomavirus (similar to SV40) that integrated itself into the genome of $80 \%$ of the Merkel cell carcinomas they examined. Though a rare cancer, this is another example of a virus-associated cancer which could be a target for cancer-preventing vaccines and could be tested preclinically in GEM models.

\subsection{Legal obstacles of preclinical testing in GEM models}

In 1988 Harvard University filed the first of three exceptionally broad U.S. patents regarding the development and use of transgenic animals. Dupont (a sponsor of one of the Harvard investigators developing transgenic mice) became the exclusive licensee of transgenic patents and merely sublicensed the patent rights (imposing large fees and restrictions) to industry and academia. This arrangement severely constrained use of transgenic mice beyond basic discovery applications (reviewed in Sharpless \& Depinho, 2006). Fortunately for the greater scientific community, the first of these patents expired in 2005 and the second expired in February 2009; the third patent covering testing methods using transgenic oncomice is still in force through 2016. Hundreds of oncomice have been developed (primarily in academia), but have yet to be thoroughly studied and used on a large scale to test the growing number of possible anti-cancer therapies. Once the final restriction is lifted, researchers in industry, academia, and government alike will undoubtedly expand their use of transgenic models for preclinical drug studies.

\section{Conclusion: Role GEMs can play in preclinical studies}

To process the thousands of novel natural product and synthetic purported anti-cancer compounds that arise each year, preclinical drug screens must be as quick and comprehensive as resources allow. This can best be accomplished by in vitro screens using cultured cell lines that have oncogenic gene expression profiles similar to those seen in human patients. Compounds which show activity can then be moved to xenograft studies, which test toxicity and tumor regression potential. Although we have reviewed the power of GEM models in verifying drug efficacy and pathway mechanism analysis, GEM models as they exist today have fundamental flaws that preclude their use as high-throughput drug-screening tools.

GEMs require several months to develop tumors, and the penetrance is often far less than $100 \%$. Tumors arise and grow at different rates in each individual mouse in a given study. Except for melanoma, breast cancer, and some prostate cancer models where palpable tumors develop, identifying which animals have developed tumors at any given moment becomes a nearly insurmountable task. Many published studies use MRI images to follow tumor progression. Considering imaging the thorax of one mouse in an MRI can take up to one hour, this method is incompatible with large, high throughput studies. Small animal in vivo imaging (SAIVI) using fluorescent or bioluminescent tagged agents targeting tumors is a promising alternative, but the technology is still in its infancy, lacks appropriate inducible GEM models for most forms of cancer, and often requires purchase of expensive, photosensitive probes and detection systems. Computed Tomography (CT) Imaging with clinical-size instruments cannot be used because the dose of radiation used during imaging may have therapeutic effects on the tumors, especially when GEM models will require 
multiple imaging sessions over their lifetime to first identify a tumor and then to monitor therapeutic drug effects. However as smaller, less powerful, rodent-specific CT imagers become available to researchers, this may prove to be a useful method to measure tumor size in deep tissue. To best utilize current GEM models in preclinical drug trials, traditional tumor staging strategies must be revised so that each mouse is treated as a patient in a clinical trial. Therapeutic agents must not be administered en mass to all individuals in a treatment group at a given time point, but tailored to each mouse reflecting the date the tumor was recognized by whatever modality the researcher has developed. This can create a logistical nightmare, especially if large combination therapy treatment trials testing multiple vehicles, routes of administration, dosing schedules, and multiple dose concentrations are attempted. Day 0 should be marked at the time an animal's measured tumor size or total "tumor burden" (if the GEM generates multiple foci simultaneously) crosses a predetermined threshold quantity.

Therefore, we cannot envision GEM models replacing in vitro and xenograft models for the high throughput efficacy screens of novel agents. However, we do believe GEM models can be of great value during three steps in the preclinical process (Figure 1). First, if GEM tumors are harvested and fragments successfully implanted subcutaneously (SC) or orthotopically into syngeneic, immune competent mice, enough animals can be amassed to perform traditional xenograft-like screens with genetically desirable murine tumors (allografts). Varticovski et al., (2007) provide an example of this approach, harvesting MMTV-PyMT breast tumors from a few mice and passing them as fragments or cell suspensions into numerous host animals for subsequent drug studies. DNA microarrays were used to verify only slight changes in gene expression after two serial passages from the original tumor. Second passage tumors exhibited similar sensitivity to paclitaxel and cyclophosphamide compared to the original tumor material.

Once an agent shows activity in vitro and in tumor transplants, GEM models can be used to explore the drug mechanism and further optimize in vivo dosing before an agent heads into the much more expensive and laborious clinical trials (Figure 1). These optimization studies need not be high throughput and may take a year or more to complete. Thus, fewer anticancer agents will successfully pass through these additional preclinical evaluations than do currently advance to clinical trial. Currently, only $~ 5 \%$ of novel anti-cancer agents entering clinical trials achieve FDA approval (Kola \& Landis, 2004); most of the cost and attrition occurs during Phase II and Phase III clinical trials. Therefore any extra time GEM-based drug screening would add to the preclinical drug development pipeline should be financially worthwhile to the drug sponsors and ethically beneficial for the volunteers participating in clinical trials if more efficacious therapies are discovered.

GEM models may ultimately have a fourth role in preclinical drug testing if researchers can effectively "humanize" them for use in toxicology and pharmacology studies. The cytochrome P450 (CYP) family of enzymes are expressed primarily in the liver and are involved in the metabolism of a diverse range of therapeutic compounds, toxins, carcinogens, hormones, and xenobiotic agents we may encounter. The seven main CYP gene clusters found in humans are present and expanded in mice (57 putative human CYP genes versus 102 putative functional genes in mice) (Nelson et al., 2004). But studies have shown that many individual CYPs are differentially expressed or differentially active between the mouse and human (Bogaards et al., 2000). This explains why drug metabolism in the mouse does not always reflect and predict drug metabolism and toxicity in the human clinical trials. Several GEM models have been generated in which the endogenous mouse CYPs or 
other xenobiotic-related metabolism genes are deleted and replaced with their human orthologues, or simply over express the human orthologue in addition to the mouse CYP (reviewed in Cheung \& Gonzalez, 2008). Expression of one or two human genes certainly is not enough to declare a potential GEM model as functionally "humanized" and ready for high throughput toxicity and pharmacology studies. But as transgenic technology evolves and these mice express numerous human orthologues, they may indeed be able to better predict human drug activity and toxicity, and be of vital importance in preclinical therapeutic drug development.

\section{References}

Abate-Shen C, Brown PH, Colburn NH, Gerner EW, Green JE, Lipkin M, Nelson WG, Threadgill D. (2008). The untapped potential of genetically engineered mouse models in chemoprevention research: opportunities and challenges. Cancer Prev Res (Phila Pa). 1(3):161-6.

Adams JM, Harris AW, Pinkert CA, Corcoran LM, Alexander WS, Cory S, Palmiter RD, Brinster RL. (1985). The c-myc oncogene driven by immunoglobulin enhancers induces lymphoid malignancy in transgenic mice. Nature. 318(6046):533-8.

Aguirre AJ, Bardeesy N, Sinha M, Lopez L, Tuveson DA, Horner J, Redston MS, DePinho RA. (2003). Activated Kras and Ink4a/Arf deficiency cooperate to produce metastatic pancreatic ductal adenocarcinoma. Genes Dev. 17(24):3112-26.

Almoguera, C.; Shibata, D.; Forrester, K.; Martin, J.; Arnheim, N.; Perucho, M. (1988). Most human carcinomas of the exocrine pancreas contain mutant c-K-ras genes. Cell. 53: 549-554.

American Cancer Society (ACS). (2010). Cancer Facts \& Figures 2010. Atlanta: American Cancer Society.

Arbeit JM, Münger K, Howley PM, Hanahan D. (1993). Neuroepithelial carcinomas in mice transgenic with human papillomavirus type 16 E6/E7 ORFs. Am J Pathol. 142(4):1187-97.

Bittner JJ. Some possible effects of nursing on the mammary gland tumor incidence in mice. Science. 1936; 84:162.

Bockamp E, Christel C, Hameyer D, Khobta A, Maringer M, Reis M, Heck R, CabezasWallscheid N, Epe B, Oesch-Bartlomowicz B, Kaina B, Schmitt S, Eshkind L. (2007). Generation and characterization of tTS-H4: a novel transcriptional repressor that is compatible with the reverse tetracycline-controlled TET-ON system. J Gene Med. 9(4):308-18.

Bogaards JJ, Bertrand M, Jackson P, Oudshoorn MJ, Weaver RJ, van Bladeren PJ, Walther B. (2000). Determining the best animal model for human cytochrome P450 activities: a comparison of mouse, rat, rabbit, dog, micropig, monkey and man. Xenobiotica. 30(12):1131-52.

Brault V, Besson V, Magnol L, Duchon A, Hérault Y. (2007). Cre/loxP-mediated chromosome engineering of the mouse genome. Handb Exp Pharmacol. (178):2948.

Brekken RA, Overholser JP, Stastny VA, Waltenberger J, Minna JD, Thorpe PE. (2000). Selective inhibition of vascular endothelial growth factor (VEGF) receptor 2 
(KDR/Flk-1) activity by a monoclonal anti-VEGF antibody blocks tumor growth in mice. Cancer Res. 60(18):5117-24.

Brinster RL, Chen HY, Messing A, van Dyke T, Levine AJ, Palmiter RD. (1984). Transgenic mice harboring SV40 T-antigen genes develop characteristic brain tumors. Cell. 37(2):367-79.

Cabebe E and Wakelee H. (2007). Role of anti-angiogenesis agents in treating NSCLC: focus on bevacizumab and VEGFR tyrosine kinase inhibitors. Curr Treat Options Oncol. 8(1):15-27.

Charles River Laboratories Rapid Expansion Services. (2006). In: Assisted Reproductive Technologies. Charles River Laboratories. 1 July 2011. Available from:

<http://www.criver.com/sitecollectiondocuments/rm_tg_d_sperm_ovarian_cryo preservation.pdf>

Chen Z, Trotman LC, Shaffer D, Lin HK, Dotan ZA, Niki M, Koutcher JA, Scher HI, Ludwig T, Gerald W, Cordon-Cardo C, Pandolfi PP. (2005). Crucial role of p53-dependent cellular senescence in suppression of Pten-deficient tumorigenesis. Nature. 436(7051):725-30.

Cheung C, Gonzalez FJ. (2008). Humanized mouse lines and their application for prediction of human drug metabolism and toxicological risk assessment. J Pharmacol Exp Ther. 327(2):288-99.

Clinicaltrials.gov. n.d. U.S. National Institutes of Health. 1 July 2011. Available from: $<$ http://www.clinicaltrials.gov/ct2/home>

Decker S, Hollingshead M, Bonomi CA, Carter JP, Sausville EA. (2004). The hollow fibre model in cancer drug screening: the NCI experience. Eur J Cancer. 40(6):821-6.

Di Cristofano A, De Acetis M, Koff A, Cordon-Cardo C, Pandolfi PP. (2001). Pten and p27KIP1 cooperate in prostate cancer tumor suppression in the mouse. Nat Genet. 27(2):222-4.

Donehower LA, Harvey M, Slagle BL, McArthur MJ, Montgomery CA Jr, Butel JS, Bradley A. (1992). Mice deficient for p53 are developmentally normal but susceptible to spontaneous tumours. Nature. 356(6366):215-21.

eMICE. electronic Models Information, Communication, and Education. n.d. National Cancer Institute. 1 July 2011. Available from:

<http://emice.nci.nih.gov/acquiring-models/Mice>

Engelman JA, Zejnullahu K, Mitsudomi T, Song Y, Hyland C, Park JO, Lindeman N, Gale CM, Zhao X, Christensen J, Kosaka T, Holmes AJ, Rogers AM, Cappuzzo F, Mok T, Lee C, Johnson BE, Cantley LC, Jänne PA. (2007). MET amplification leads to gefitinib resistance in lung cancer by activating ERBB3 signaling. Science. 316(5827):1039-43.

Feng H, Shuda M, Chang Y, Moore PS. (2008). Clonal integration of a polyomavirus in human Merkel cell carcinoma. Science. 319(5866):1096-100.

Fisher GH, Wellen SL, Klimstra D, Lenczowski JM, Tichelaar JW, Lizak MJ, Whitsett JA, Koretsky A, Varmus HE. (2001). Induction and apoptotic regression of lung adenocarcinomas by regulation of a K-Ras transgene in the presence and absence of tumor suppressor genes. Genes Dev. 15(24):3249-62. 
Freundlieb S, Schirra-Müller C, Bujard H. (1999). A tetracycline controlled activation/repression system with increased potential for gene transfer into mammalian cells. J Gene Med. 1(1):4-12.

Gray IC, Stewart LM, Phillips SM, Hamilton JA, Gray NE, Watson GJ, Spurr NK, Snary D. (1998). Mutation and expression analysis of the putative prostate tumoursuppressor gene PTEN. Br J Cancer. 78(10):1296-300.

Guix M, Faber AC, Wang SE, Olivares MG, Song Y, Qu S, Rinehart C, Seidel B, Yee D, Arteaga CL, Engelman JA. (2008). Acquired resistance to EGFR tyrosine kinase inhibitors in cancer cells is mediated by loss of IGF-binding proteins. J Clin Invest. 118(7):2609-19.

Guy CT, Cardiff RD, Muller WJ. (1992). Induction of mammary tumors by expression of polyomavirus middle $\mathrm{T}$ oncogene: a transgenic mouse model for metastatic disease. Mol Cell Biol. 12(3):954-61.

Han SW, Kim TY, Hwang PG, Jeong S, Kim J, Choi IS, Oh DY, Kim JH, Kim DW, Chung DH, Im SA, Kim YT, Lee JS, Heo DS, Bang YJ, Kim NK. (2005). Predictive and prognostic impact of epidermal growth factor receptor mutation in non-small-cell lung cancer patients treated with gefitinib. J Clin Oncol. 23(11):2493-501.

Hanahan D. (1985). Heritable formation of pancreatic beta-cell tumours in transgenic mice expressing recombinant insulin/simian virus 40 oncogenes. Nature. 315(6015):11522.

Hanahan D and Weinberg RA. (2000). The hallmarks of cancer. Cell. 100: 57-70.

Harris CC and Hollstein M. (1993). Clinical implications of the p53 tumor-suppressor gene. New Eng. J. Med. 329: 1318-1327.

Heston WE and Parks WP. (1977). Mammary tumors and mammary tumor virus expression in hybrid mice of strains C57BL and GR. J. Exp. Med. 146: 1206-1220.

Huang AL, Ostrowski MC, Berard D, Hager GL. (1981). Glucocorticoid regulation of the HaMuSV p21 gene conferred by sequences from mouse mammary tumor virus. Cell. 27(2 Pt 1):245-55.

Huang S, Li Y, Chen Y, Podsypanina K, Chamorro M, Olshen AB, Desai KV, Tann A, Petersen D, Green JE, Varmus HE. (2005). Changes in gene expression during the development of mammary tumors in MMTV-Wnt-1 transgenic mice. Genome Biol. 6(10):R84.

Jacks T, Fazeli A, Schmitt EM, Bronson RT, Goodell MA, Weinberg RA. (1992). Effects of an $\mathrm{Rb}$ mutation in the mouse. Nature. 359(6393):295-300.

Jackson EL, Willis N, Mercer K, Bronson RT, Crowley D, Montoya R, Jacks T, Tuveson DA. (2001). Analysis of lung tumor initiation and progression using conditional expression of oncogenic K-ras. Genes Dev. 15(24):3243-8.

JAX® Speed Expansion Service. n.d. The Jackson Laboratory. 1 July 2011. Available from: <http://jaxservices.jax.org/breeding/speed-expansion.html>

Ji H, Li D, Chen L, Shimamura T, Kobayashi S, McNamara K, Mahmood U, Mitchell A, Sun Y, Al-Hashem R, Chirieac LR, Padera R, Bronson RT, Kim W, Jänne PA, Shapiro GI, Tenen D, Johnson BE, Weissleder R, Sharpless NE, Wong KK. (2006). The impact of human EGFR kinase domain mutations on lung tumorigenesis and in vivo sensitivity to EGFR-targeted therapies. Cancer Cell. 9(6):485-95. 
Ji H, Ramsey MR, Hayes DN, Fan C, McNamara K, Kozlowski P, Torrice C, Wu MC, Shimamura T, Perera SA, Liang MC, Cai D, Naumov GN, Bao L, Contreras CM, Li D, Chen L, Krishnamurthy J, Koivunen J, Chirieac LR, Padera RF, Bronson RT, Lindeman NI, Christiani DC, Lin X, Shapiro GI, Jänne PA, Johnson BE, Meyerson M, Kwiatkowski DJ, Castrillon DH, Bardeesy N, Sharpless NE, Wong KK. (2007). LKB1 modulates lung cancer differentiation and metastasis. Nature. 448(7155): 807-10.

Johnson L, Mercer K, Greenbaum D, Bronson RT, Crowley D, Tuveson DA, and Jacks T. (2001). Somatic activation of the K-ras oncogene causes early onset lung cancer in mice. Nature. 410: 1111-1116.

Jonkers J, Meuwissen R, van der Gulden H, Peterse H, van der Valk M, Berns A. (2001). Synergistic tumor suppressor activity of BRCA2 and p53 in a conditional mouse model for breast cancer. Nature Genet. 29: 418-425.

Jumbe NL, Xin Y, Leipold DD, Crocker L, Dugger D, Mai E, Sliwkowski MX, Fielder PJ, Tibbitts J. (2010). Modeling the efficacy of trastuzumab-DM1, an antibody drug conjugate, in mice. J Pharmacokinet Pharmacodyn. 37(3):221-42.

Kerbel RS. (2003). Human tumor xenografts as predictive preclinical models for anticancer drug activity in humans: better than commonly perceived-but they can be improved. Cancer Biol Ther. 2(4 Suppl 1):S134-9.

Kim ES and Salgia R. (2009). MET pathway as a therapeutic target. J Thorac Oncol. 4(4): 444-7.

Kobayashi S, Boggon TJ, Dayaram T, Jänne PA, Kocher O, Meyerson M, Johnson BE, Eck MJ, Tenen DG, Halmos B. (2005). EGFR mutation and resistance of non-small-cell lung cancer to gefitinib. N Engl J Med. 352:786-792.

Kohl NE, Omer CA, Conner MW, Anthony NJ, Davide JP, deSolms SJ, Giuliani EA, Gomez RP, Graham SL, Hamilton K, Handt LK, Hartman GE, Koblan KS, Kral AM, Miller PJ, Mosser SD, O’Neil TJ, Rands E, Schaber MD, Gibbs JB, Oliff A. (1995). Inhibition of farnesyltransferase induces regression of mammary and salivary carcinomas in ras transgenic mice. Nat Med. 1(8):792-797.

Kola I and Landis J. (2004). Can the pharmaceutical industry reduce attrition rates? Nat Rev Drug Discov. 3(8):711-5.

Kranenburg O. (2005). The KRAS oncogene: past, present, and future. Biochim. Biophys. Acta. 1756: 81-82.

Kulke MH, Demetri GD, Sharpless NE, Ryan DP, Shivdasani R, Clark JS, Spiegelman BM, Kim H, Mayer RJ, Fuchs CS. (2002). A phase II study of troglitazone, an activator of the PPARgamma receptor, in patients with chemotherapy-resistant metastatic colorectal cancer. Cancer J. 8(5):395-9.

Kung HC, Hoyert D, Xu J, and Murphy SL. (2008). Deaths: Final Data for 2005. National Vital Statistics Reports. 56(10):5.

Lambert PF, Pan H, Pitot HC, Liem A, Jackson M, Griep AE. (1993). Epidermal cancer associated with expression of human papillomavirus type 16 E6 and E7 oncogenes in the skin of transgenic mice. Proc Natl Acad Sci USA. 90(12):5583-7.

Le $\mathrm{Y}$ and Sauer B. (2001). Conditional Gene Knockout Using Cre Recombinase. Molecular Biotechnology. 17: 269-275. 
Lynch TJ, Bell DW, Sordella R, Gurubhagavatula S, Okimoto RA, Brannigan BW, Harris PL, Haserlat SM, Supko JG, Haluska FG, Louis DN, Christiani DC, Settleman J, Haber DA. (2004). Activating mutations in the epidermal growth factor receptor underlying responsiveness of non-small-cell lung cancer to gefitinib. $N$ Engl J Med 350:2129-2139.

Maglione JE, McGoldrick ET, Young LJ, Namba R, Gregg JP, Liu L, Moghanaki D, Ellies LG, Borowsky AD, Cardiff RD, MacLeod CL. (2004). Polyomavirus middle T-induced mammary intraepithelial neoplasia outgrowths: single origin, divergent evolution, and multiple outcomes. Mol Cancer Ther. 3(8):941-53.

Maguire HC Jr and Greene MI. (1989). The neu (c-erbB-2) oncogene. Semin Oncol.16(2):14855.

Malkinson AM. (1998). Molecular comparison of human and mouse pulmonary adenocarcinomas. Exp Lung Res. 24(4):541-55.

Mangues R, Corral T, Kohl NE, Symmans WF, Lu S, Malumbres M, Gibbs JB, Oliff A, Pellicer A. (1998). Antitumor effect of a farnesyl protein transferase inhibitor in mammary and lymphoid tumors overexpressing N-Ras in transgenic mice. Cancer Res. 58(6):1253-1259.

Marino S, Vooijs M, van der Gulden H, Jonker J, Berns A. (2000). Induction of medulloblastomas in p53-null mutant mice by somatic inactivation of $\mathrm{Rb}$ in the external granular layer cells of the cerebellum. Genes Dev. 14: 994-1004.

Marty M, Cognetti F, Maraninchi D, Snyder R, Mauriac L, Tubiana-Hulin M, Chan S, Grimes D, Antón A, Lluch A, Kennedy J, O'Byrne K, Conte P, Green M, Ward C, Mayne K, Extra JM. (2005). Randomized phase II trial of the efficacy and safety of trastuzumab combined with docetaxel in patients with human epidermal growth factor receptor 2-positive metastatic breast cancer administered as first-line treatment: the M77001 study group. J Clin Oncol. 23(19):4265-74.

McLemore MR. (2006). Gardasil: Introducing the new human papillomavirus vaccine. Clin J Oncol Nurs. 10(5):559-60.

Mendola CE, Backer JM. (1990). Lovastatin blocks N-ras oncogene-induced neuronal differentiation. Cell Growth Differ. 1(10):499-502.

Michel A, Kopp-Schneider A, Zentgraf H, Gruber AD, de Villiers EM. (2006). E6/E7 expression of human papillomavirus type 20 (HPV-20) and HPV-27 influences proliferation and differentiation of the skin in UV-irradiated SKH-hr1 transgenic mice. J Virol. 80(22):11153-64.

Monks A, Scudiero D, Skehan P, Shoemaker R, Paull K, Vistica D, Hose C, Langley J, Cronise P, Vaigro-Wolff A, Gray-Goodrich M, Campbell H, Mayo J, Boyd M. (1991). Feasibility of a high-flux anticancer drug screen using a diverse panel of cultured human tumor cell lines. J Natl Cancer Inst. 83(11):757-66.

Morita S, Okamoto I, Kobayashi K, Yamazaki K, Asahina H, Inoue A, Hagiwara K, Sunaga N, Yanagitani N, Hida T, Yoshida K, Hirashima T, Yasumoto K, Sugio K, Mitsudomi T, Fukuoka M, Nukiwa T. (2009). Combined survival analysis of prospective clinical trials of gefitinib for non-small cell lung cancer with EGFR mutations. Clin Cancer Res. 15(13):4493-8.

Murgo AJ, Kummar S, Rubinstein L, Gutierrez M, Collins J, Kinders R, Parchment RE, Ji J, Steinberg SM, Yang SX, Hollingshead M, Chen A, Helman L, Wiltrout R, 
Tomaszewski JE, Doroshow JH. (2008). Designing phase 0 cancer clinical trials. Clin Cancer Res. 14(12):3675-82.

Nagy A and Mar L. (2001). Creation and Use of a Cre Recombinase Transgenic Database. Methods Mol Biol 158:95-106. Database available from:

<http://nagy.mshri.on.ca/cre/index.php>

Nanda R. (2007). Targeting the human epidermal growth factor receptor 2 (HER2) in the treatment of breast cancer: recent advances and future directions. Rev Recent Clin Trials. 2(2):111-6.

Nelson DR, Zeldin DC, Hoffman SM, Maltais LJ, Wain HM, Nebert DW. (2004). Comparison of cytochrome P450 (CYP) genes from the mouse and human genomes, including nomenclature recommendations for genes, pseudogenes and alternative-splice variants. Pharmacogenetics. 14(1):1-18.

Ohashi K, Takigawa N, Osawa M, Ichihara E, Takeda H, Kubo T, Hirano S, Yoshino T, Takata M, Tanimoto M, Kiura K. (2009). Chemopreventive Effects of Gefitinib on Nonsmoking-Related Lung Tumorigenesis in Activating Epidermal Growth Factor Receptor Transgenic Mice. Cancer Res. 69(17):7088-7095.

Omer CA, Chen Z, Diehl RE, Conner MW, Chen HY, Trumbauer ME, Gopal-Truter S, Seeburger G, Bhimnathwala H, Abrams MT, Davide JP, Ellis MS, Gibbs JB, et al. (2000). Mouse mammary tumor virus-Ki-rasB transgenic mice develop mammary carcinomas that can be growth-inhibited by a farnesyl:protein transferase inhibitor. Cancer Res. 60(10):2680-2688.

Ornitz DM, Palmiter RD, Messing A, Hammer RE, Pinkert CA, Brinster RL. (1985). Elastase I promoter directs expression of human growth hormone and SV40 T antigen genes to pancreatic acinar cells in transgenic mice. Cold Spring Harb Symp Quant Biol. 50:399-409.

Paez JG, Jänne PA, Lee JC, Tracy S, Greulich H, Gabriel S, Herman P, Kaye FJ, Lindeman N, Boggon TJ, Naoki K, Sasaki H, Fujii Y, Eck MJ, Sellers WR, Johnson BE, Meyerson M. (2004). EGFR mutations in lung cancer: correlation with clinical response to gefitinib therapy. Science. 304(5676):1497-500.

Palmiter RD, Chen HY, Messing A, Brinster RL. (1985). SV40 enhancer and large-T antigen are instrumental in development of choroid plexus tumours in transgenic mice. Nature. 316(6027):457-60.

Palmiter RD, Brinster RL. (1986). Germ-line transformation of mice. Annu Rev Genet. 20:46599.

Pao W, Miller VA, Politi KA, Riely GJ, Somwar R, Zakowski MF, Kris MG, Varmus H. (2005). Acquired resistance of lung adenocarcinomas to gefitinib or erlotinib is associated with a second mutation in the EGFR kinase domain. PLoS Med. 2(3):e73.

Politi K, Zakowski MF, Fan PD, Schonfeld EA, Pao W, Varmus HE. (2006). Lung adenocarcinomas induced in mice by mutant EGF receptors found in human lung cancers respond to a tyrosine kinase inhibitor or to down-regulation of the receptors. Genes Dev. 20(11):1496-510.

Poole AJ, Li Y, Kim Y, Lin SC, Lee WH, Lee EY. (2006). Prevention of Brca1-mediated mammary tumorigenesis in mice by a progesterone antagonist. Science. 314: 14671470. 
Quaife CJ, Pinkert CA, Ornitz DM, Palmiter RD, Brinster RL (1987). Pancreatic neoplasia induced by ras expression in acinar cells of transgenic mice. Cell. 48(6):1023-34.

Rao PN, Freireich EJ, Smith ML, Loo TL. (1979). Cell cycle phase-specific cytotoxicity of the antitumor agent maytansine. Cancer Res. 39(8):3152-5.

Remillard S, Rebhun LI, Howie GA, Kupchan SM. (1975). Antimitotic activity of the potent tumor inhibitor maytansine. Science. 189(4207):1002-5.

Riely GJ. (2008). Second-generation epidermal growth factor receptor tyrosine kinase inhibitors in non-small cell lung cancer. J Thorac Oncol. 3(6 Suppl 2):S146-9.

Robles AI and Varticovski L. (2008). Harnessing genetically engineered mouse models for preclinical testing. Chem Biol Interact. 171(2):159-64.

Rowell CA, Kowalczyk JJ, Lewis MD, Garcia AM. (1997). Direct demonstration of geranylgeranylation and farnesylation of Ki-Ras in vivo. J Biol Chem. 272 (22):1409314097.

Saez E, Tontonoz P, Nelson MC, Alvarez JG, Ming UT, Baird SM, Thomazy VA, Evans RM. (1998). Activators of the nuclear receptor PPARgamma enhance colon polyp formation. Nat Med. 4(9):1058-61.

Sarraf P, Mueller E, Jones D, King FJ, DeAngelo DJ, Partridge JB, Holden SA, Chen LB, Singer S, Fletcher C, Spiegelman BM. (1998). Differentiation and reversal of malignant changes in colon cancer through PPARgamma. Nat Med. 4(9):104652.

Schaper ID, Marcuzzi GP, Weissenborn SJ, Kasper HU, Dries V, Smyth N, Fuchs P, Pfister H. (2005). Development of skin tumors in mice transgenic for early genes of human papillomavirus type 8. Cancer Res. 65(4):1394-400.

Sequist LV, Martins RG, Spigel D, Grunberg SM, Spira A, Jänne PA, Joshi VA, McCollum D, Evans TL, Muzikansky A, Kuhlmann GL, Han M, Goldberg JS, Settleman J, Iafrate AJ, Engelman JA, Haber DA, Johnson BE, Lynch TJ. (2008). First-line gefitinib in patients with advanced non-small-cell lung cancer harboring somatic EGFR mutations. J Clin Oncol. 26(15):2442-9.

Sharpless NE and Depinho RA. (2006). The mighty mouse: genetically engineered mouse models in cancer drug development. Nat Rev Drug Discov. 5(9):741-54.

Shepherd FA, Rodrigues Pereira J, Ciuleanu T, Tan EH, Hirsh V, Thongprasert S, Campos D, Maoleekoonpiroj S, Smylie M, Martins R, van Kooten M, Dediu M, Findlay B, Tu D, Johnston D, Bezjak A, Clark G, Santabárbara P, Seymour L; National Cancer Institute of Canada Clinical Trials Group. (2005). Erlotinib in previously treated non-small-cell lung cancer. N Engl J Med. 353(2):123-32.

Shimamura T, Li D, Ji H, Haringsma HJ, Liniker E, Borgman CL, Lowell AM, Minami Y, McNamara K, Perera SA, Zaghlul S, Thomas RK, Greulich H, Kobayashi S, Chirieac LR, Padera RF, Kubo S, Takahashi M, Tenen DG, Meyerson M, Wong KK, Shapiro GI. (2008). Hsp90 inhibition suppresses mutant EGFR-T790M signaling and overcomes kinase inhibitor resistance. Cancer Res. 68(14):5827-38.

Slamon DJ, Leyland-Jones B, Shak S, Fuchs H, Paton V, Bajamonde A, Fleming T, Eiermann W, Wolter J, Pegram M, Baselga J, Norton L. (2001). Use of chemotherapy plus a monoclonal antibody against HER2 for metastatic breast cancer that overexpresses HER2. N Engl J Med. 2001 Mar 15; 344(11):783-92. 
Sos ML, Michel K, Zander T, Weiss J, Frommolt P, Peifer M, Li D, Ullrich R, Koker M, Fischer F, Shimamura T, Rauh D, Mermel C, Fischer S, Stückrath I, Heynck S, et al. (2009). Predicting drug susceptibility of non-small cell lung cancers based on genetic lesions. J Clin Invest. 119(6):1727-40.

Sprengel R, Hasan MT. (2007). Tetracycline-controlled genetic switches. Handb Exp Pharmacol. (178):49-72.

Stewart TA, Pattengale PK, Leder P. (1984). Spontaneous mammary adenocarcinomas in transgenic mice that carry and express MTV/myc fusion genes. Cell. 38(3):62737.

Strasser A, Harris AW, Bath ML, Cory S. (1990). Novel primitive lymphoid tumours induced in transgenic mice by cooperation between myc and bcl-2. Nature. 348(6299):331-3.

Sun J, Qian Y, Hamilton AD, Sebti SM. (1998). Both farnesyltransferase and geranylgeranyltransferase I inhibitors are required for inhibition of oncogenic KRas prenylation but each alone is sufficient to suppress human tumor growth in nude mouse xenografts. Oncogene. 16(11):1467-1473.

Syrjänen S. (2005). Human papillomavirus (HPV) in head and neck cancer. J Clin Virol. 32 Suppl 1:S59-66.

Trotman LC, Niki M, Dotan ZA, Koutcher JA, Di Cristofano A, Xiao A, Khoo AS, RoyBurman P, Greenberg NM, Van Dyke T, Cordon-Cardo C, Pandolfi PP. (2003). Pten dose dictates cancer progression in the prostate. PLoS Biol. 1(3):E59.

Varticovski L, Hollingshead MG, Robles AI, Wu X, Cherry J, Munroe DJ, Lukes L, Anver MR, Carter JP, Borgel SD, Stotler H, Bonomi CA, Nunez NP, Hursting SD, Qiao W, Deng CX, Green JE, Hunter KW, Merlino G, Steeg PS, Wakefield LM, Barrett JC. (2007). Accelerated preclinical testing using transplanted tumors from genetically engineered mouse breast cancer models. Clin Cancer Res. 13(7):2168-77.

Ventura A, Kirsch DG, McLaughlin ME, Tuveson DA, Grimm J, Lintault L, Newman J, Reczek EE, Weissleder R, Jacks T. (2007). Restoration of p53 function leads to tumour regression in vivo. Nature. 445(7128):661-5.

Wang S, Gao J, Lei Q, Rozengurt N, Pritchard C, Jiao J, Thomas GV, Li G, Roy-Burman P, Nelson PS, Liu X, Wu H. (2003). Prostate-specific deletion of the murine Pten tumor suppressor gene leads to metastatic prostate cancer. Cancer Cell. 4(3):209-21.

Weinstein IB. (2002). Addiction to oncogenes--the Achilles heal of cancer. Science. 297(5578): 63-4.

Winslow MM, Dayton TL, Verhaak RG, Kim-Kiselak C, Snyder EL, Feldser DM, Hubbard DD, Dupage MJ, Whittaker CA, Hoersch S, Yoon S, Crowley D, Bronson RT, Chiang DY, Meyerson M, Jacks T. (2011). Suppression of lung adenocarcinoma progression by Nkx2-1. Nature. 473(7345):101-4.

Yang CH, Yu CJ, Shih JY, Chang YC, Hu FC, Tsai MC, Chen KY, Lin ZZ, Huang CJ, Shun CT, Huang CL, Bean J, Cheng AL, Pao W, Yang PC. (2008). Specific EGFR mutations predict treatment outcome of stage IIIB/IV patients with chemotherapynaive non-small-cell lung cancer receiving first-line gefitinib monotherapy. J Clin Oncol. 26(16):2745-53. 
Yun CH, Mengwasser KE, Toms AV, Woo MS, Greulich H, Wong KK, Meyerson M, Eck MJ. (2008). The T790M mutation in EGFR kinase causes drug resistance by increasing the affinity for ATP. Proc Natl Acad Sci USA. 105(6):2070-5.

Zenker M, Lehmann K, Schulz AL, Barth H, Hansmann D, Koenig R, Korinthenberg R, Kreiss-Nachtsheim M, Meinecke P, Morlot S, Mundlos S, Quante AS, Raskin S, Schnabel D, Wehner LE, Kratz CP, Horn D, Kutsche K. (2007). Expansion of the genotypic and phenotypic spectrum in patients with KRAS germline mutations. J. Med. Genet. 44:131-135.

Zhu K, Hamilton AD, Sebti SM. (2003). Farnesyltransferase inhibitors as anticancer agents: current status. Curr Opin Investig Drugs. 4(12):1428-35. 


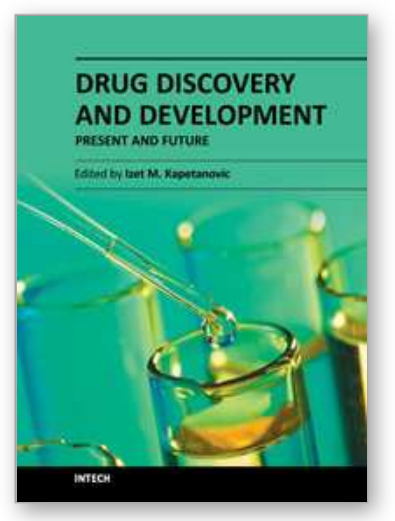

\author{
Drug Discovery and Development - Present and Future \\ Edited by Dr. Izet Kapetanović
}

ISBN 978-953-307-615-7

Hard cover, 528 pages

Publisher InTech

Published online 16, December, 2011

Published in print edition December, 2011

Drug discovery and development process aims to make available medications that are safe and effective in improving the length and quality of life and relieving pain and suffering. However, the process is very complex, time consuming, resource intensive, requiring multi-disciplinary expertise and innovative approaches. There is a growing urgency to identify and develop more effective, efficient, and expedient ways to bring safe and effective products to the market. The drug discovery and development process relies on the utilization of relevant and robust tools, methods, models, and validated biomarkers that are predictive of clinical effects in terms of diagnosis, prevention, therapy, and prognosis. There is a growing emphasis on translational research, a bidirectional bench to the bedside approach, in an effort to improve the process efficiency and the need for further innovations. The authors in the book discuss the current and evolving state of drug discovery and development.

\title{
How to reference
}

In order to correctly reference this scholarly work, feel free to copy and paste the following:

Sergio Y. Alcoser and Melinda G. Hollingshead (2011). Genetically Engineered Mouse Models in Preclinical Anti-Cancer Drug Development, Drug Discovery and Development - Present and Future, Dr. Izet Kapetanović (Ed.), ISBN: 978-953-307-615-7, InTech, Available from: http://www.intechopen.com/books/drug-discoveryand-development-present-and-future/genetically-engineered-mouse-models-in-preclinical-anti-cancer-drugdevelopment

\section{INTECH}

open science | open minds

\section{InTech Europe}

University Campus STeP Ri

Slavka Krautzeka 83/A

51000 Rijeka, Croatia

Phone: +385 (51) 770447

Fax: +385 (51) 686166

www.intechopen.com

\section{InTech China}

Unit 405, Office Block, Hotel Equatorial Shanghai

No.65, Yan An Road (West), Shanghai, 200040, China

中国上海市延安西路65号上海国际贵都大饭店办公楼 405 单元

Phone: +86-21-62489820

Fax: $+86-21-62489821$ 
(C) 2011 The Author(s). Licensee IntechOpen. This is an open access article distributed under the terms of the Creative Commons Attribution 3.0 License, which permits unrestricted use, distribution, and reproduction in any medium, provided the original work is properly cited. 